\title{
Synthesis, Characterization and Antimicrobial Screening of Metal Complexes of Mannich Bases Derived from Benzimidazole
}

\author{
A. ABDUL JAMEEL ${ }^{1}$, M. SYED ALI PADUSHA ${ }^{1}$, \\ K. SULTHAN SYED IBRAHIM ${ }^{2 *}$ and S. SAJENA ${ }^{1}$
}

${ }^{1}$ Department of Chemistry, Jamal Mohamed College, Tiruchirappalli-620020, Tamilnadu, India

${ }^{2}$ Department of Chemistry, Dr. Zakir Husain College, Ilayangudi - 630702, Tamilnadu, India

kssichem@gmail.com

Received 5 March 2016 / Accepted 19 March 2016

\begin{abstract}
Co}(\mathrm{II}), \mathrm{Ni}(\mathrm{II}), \mathrm{Cu}(\mathrm{II})$ and $\mathrm{Zn}(\mathrm{II})$ complexes of 2-((1H-benzo[d]imidazol-1-yl)(phenyl) methyl)hydrazinecarboxamide (BIBS) and 2-((1H-benzo[d]imidazol-1-yl)(phenyl) methyl) hydrazinecarbothioamide (BIBTS) were synthesized and characterized by elemental analysis, IR, ${ }^{1} \mathrm{H}$ NMR, ${ }^{13} \mathrm{C}$ NMR, mass, electronic spectra, magnetic moment, molar conductance and EPR studies. The complexes were found to have general formulae $\left[\mathrm{M}(\mathrm{BIBS})_{2} \mathrm{Cl}_{2}\right]$ and $\left[\mathrm{M}(\mathrm{BIBTS})_{2} \mathrm{Cl}_{2}\right][\mathrm{M}=\mathrm{Co}(\mathrm{II})$, $\mathrm{Ni}(\mathrm{II}), \mathrm{Cu}(\mathrm{II})$ and $\mathrm{Zn}(\mathrm{II})]$. The IR results demonstrate that co-ordination sites are the azomethine nitrogen and carbonyl oxygen atom of the ligand BIBS, carbonyl sulphur of the ligand BIBTS. The geometry of the complexes is confirmed by measuring number of bands, their energy positions and intensity by electronic and magnetic moment measurement values. The in vitro biological screening effects of the synthesized compounds were tested against various microbial species and the results show that the metal complexes are more biologically active than the free ligand.
\end{abstract}

Keywords: Mannich base, Metal complexes of benzimidazole, O, N and O, S donor, Antimicrobial activity

\section{Introduction}

Mannich reaction withstands a large diversity of functional groups and hence it has been witnessing a continuous growth in the field of organic chemistry. The surge of literature on Mannich reaction provides an outstanding evidence for the diversity and applications of the reaction ${ }^{1}$. Mannich bases are physiologically reactive because of the basic function rendering the molecule soluble in aqueous solvent when it is transformed into ammonium salt ${ }^{2}$. Benzimidazole and its derivatives have different activities as they can act as bacteriostats or bactericides, fungicides, anticarcinogens, etc ${ }^{3-6}$. The biological activity and pharmacological properties of the benzimidazole derivatives, have led us to investigate the coordination behavior of benzimidazole derivatives towards transition metal ions. However, bis(benzimidazole) ligands, which represent a class of aromatic $N$-donor organic linkers, 
are still less developed ${ }^{7,8}$. Investigations are going on the formation of metal complexes with benzimidazole ring containing ligands ${ }^{9}$. Therefore substituted benzimidazoles have attracted the interest of various research group, especially since it has been reported that the influence of the substitution at 1,2 and 5-positions is very important for their pharmacological effect ${ }^{10}$. A number of review articles have been published on various complexes of thiosemicarbazones and its mode of metal-coordination. In current scenario a number of researches have worked on some transition metal coordination complexes of thiosemicarbazones ${ }^{11-14}$ and reported in authentic journal. Considering the importance of drugs and their complexes it has been desired to synthesize and characterize some transition metal chloro complexes of $\mathrm{Co}(\mathrm{II}), \mathrm{Ni}(\mathrm{II}), \mathrm{Cu}$ (II) and $\mathrm{Zn}(\mathrm{II})$ with a benzimidazole derivatives BIBS and BIBTS.

\section{Experimental}

All chemicals used in the synthesis were Laboratory grade. Commercial solvents were distilled and then used for the preparation of ligand and its complexes. Compounds were routinely checked for their purity on Silica gel G (Merck) Thin layer chromatography (TLC) plates. Iodine chamber was used for visualization of TLC spots. Melting points were determined in open glass capillary tubes and are uncorrected. Microanalyses ( $\mathrm{C}, \mathrm{H}$ and $\mathrm{N}$ ) were performed in Carlo Erba 1108 analyzer at Sophisticated Analytical Instrument Facility (SAIF), Central Drug Research Institute (CDRI), Lucknow, India. IR spectra were recorded with Shimadzu FT-IR spectrophotometer in the $4500-400 \mathrm{~cm}^{-1}$ range using $\mathrm{KBr}$ pellets. NMR spectra were recorded on a JEOL-GSX-400 spectrometer in $\mathrm{CDCl}_{3}$ with TMS as the internal reference. The chemical shifts are reported in ppm scale. FAB-MS spectra were recorded with a VGZAB-HS spectrometer at room temperature in a 3-nitrobenzylalcohol matrix. Molar conductivity was determined using Systronic Conductivity Bridge with a dip type cell using $10^{-3} \mathrm{M}$ solution of complexes in DMSO. Electronic spectra were determined in ethanol on a Shimadzu UV-Vis 1700 spectrophotometer. Magnetic susceptibility measurements of the complexes were carried out by Gouy balance using copper sulfate pentahydrate as the calibrant. Electron paramagnetic resonance spectra of the mixed ligand complexes of copper(II) were recorded on a Varian E 112 EPR spectrometer in DMSO solution both at room temperature and liquid nitrogen temperature (77 K) using TCNE (tetracyanoethylene) as the g-marker. Nutrient agar was used for testing the susceptibility of microorganisms to antimicrobial agents using the disc-diffusion technique. In this study the Ligand as well as complexes were tested for their effect on certain human pathogenic bacteria, Gram positive (Staphylococcus aureus and Staphylococcus aureus), Gram negative (Pseudomonas aeruginosa and Escherichia coli) and Fungicide (Candida Albicans). The zone of inhibition was measured in $\mathrm{mm}$ and the activities were compared with Ciprofloxacin $5 \mu \mathrm{g} /$ disc for bacteria and Clotrimazole $10 \mu \mathrm{g} /$ disc for fungi.

\section{Results and Discussion}

The yellow coloured Mannich bases BIBS and BIBTS were found to be soluble in common organic solvents such as ethanol, chloroform, DMF, THF, $\mathrm{CCl}_{4}$ and DMSO, but insoluble in water. The structure of the ligand BIBS and BIBTS were elucidated on the basis of their analytical and spectral data. The observed sharp melting point of BIBS is $98{ }^{\circ} \mathrm{C}$ and BIBTS is $170{ }^{\circ} \mathrm{C}$ which indicates the purity of the ligands. The elemental analysis data (Table 1) agree well with the suggested formulae and indicates that, all the metal complexes have 1:2 (metal: ligand) stoichiometry for all complexes. The presence of chloride is evident from Volhald's method. The molar conductance of the complexes of BIBS and BIBTS were determined at a concentration $1 \times 10^{-3} \mathrm{M}$ in DMF for cobalt and nickel complexes and in DMSO for copper and zinc complexes show small values in the range 1.0-6.78 $\Omega^{-1} \mathrm{~cm}^{2} \mathrm{~mol}^{-1}$ 
respectively, indicating that the complexes are non-electrolytes. Antimicrobial activity of both ligands BIBS and BIBTS with their respective metal complexes are presented in Table 2.

Table 1. Analytical data of BIBS, BIBTS and its metal complexes

\begin{tabular}{|c|c|c|c|c|c|c|c|c|}
\hline \multirow[b]{2}{*}{ Compound } & \multirow[b]{2}{*}{ Colour } & \multirow{2}{*}{$\begin{array}{l}\sum_{\infty} \\
= \\
=\end{array}$} & \multirow{2}{*}{ 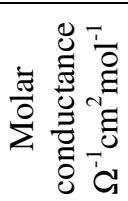 } & \multicolumn{5}{|c|}{ Found (Calculated) } \\
\hline & & & & $\mathrm{C}$ & $\mathrm{H}$ & $\mathrm{N}$ & M & $\mathrm{Cl}$ \\
\hline BIBS & Yellow & - & - & $\begin{array}{c}64.04 \\
(63.85)\end{array}$ & $\begin{array}{c}5.37 \\
(5.30)\end{array}$ & $\begin{array}{l}24.90 \\
(24.25)\end{array}$ & - & - \\
\hline$\left[\mathrm{Co}(\mathrm{BIBS})_{2} \mathrm{Cl}_{2}\right]$ & Blue & 4.60 & 2.3 & $\begin{array}{c}52.04 \\
(52.03)\end{array}$ & $\begin{array}{c}4.32 \\
(4.37)\end{array}$ & $\begin{array}{c}20.18 \\
(20.23)\end{array}$ & $\begin{array}{c}8.48 \\
(8.51)\end{array}$ & $\begin{array}{c}10.10 \\
(10.24)\end{array}$ \\
\hline$\left[\mathrm{Ni}(\mathrm{BIBS})_{2} \mathrm{Cl}_{2}\right]$ & Grey & 3.55 & 2.6 & $\begin{array}{c}52.00 \\
(52.05)\end{array}$ & $\begin{array}{c}4.31 \\
(4.37)\end{array}$ & $\begin{array}{c}20.12 \\
(20.23)\end{array}$ & $\begin{array}{c}8.41 \\
(8.48)\end{array}$ & $\begin{array}{c}10.05 \\
(10.24)\end{array}$ \\
\hline$\left[\mathrm{Cu}(\mathrm{BIBS})_{2} \mathrm{Cl}_{2}\right]$ & $\begin{array}{l}\text { Dark } \\
\text { green }\end{array}$ & 1.94 & 6.1 & $\begin{array}{c}51.61 \\
(51.69)\end{array}$ & $\begin{array}{c}4.32 \\
(4.34)\end{array}$ & $\begin{array}{c}20.17 \\
(20.09)\end{array}$ & $\begin{array}{c}9.09 \\
(9.12)\end{array}$ & $\begin{array}{l}10.10 \\
(10.17)\end{array}$ \\
\hline$\left[\mathrm{Zn}(\mathrm{BIBS})_{2} \mathrm{Cl}_{2}\right]$ & White & Dia & 1.0 & $\begin{array}{c}51.50 \\
(51.55)\end{array}$ & $\begin{array}{c}4.29 \\
(4.33)\end{array}$ & $\begin{array}{c}20.01 \\
(20.04)\end{array}$ & $\begin{array}{c}9.30 \\
(9.35)\end{array}$ & $\begin{array}{c}10.01 \\
(10.15)\end{array}$ \\
\hline BIBTS & Yellow & - & - & $\begin{array}{c}64.04 \\
(63.85)\end{array}$ & $\begin{array}{c}5.37 \\
(5.30)\end{array}$ & $\begin{array}{l}24.90 \\
(24.25)\end{array}$ & - & - \\
\hline$\left[\mathrm{Co}(\mathrm{BIBTS})_{2} \mathrm{Cl}_{2}\right]$ & Blue & 5.08 & 2.3 & $\begin{array}{c}52.04 \\
(52.03)\end{array}$ & $\begin{array}{c}4.32 \\
(4.37)\end{array}$ & $\begin{array}{c}20.18 \\
(20.23)\end{array}$ & $\begin{array}{c}8.48 \\
(8.51)\end{array}$ & $\begin{array}{l}10.10 \\
(10.24)\end{array}$ \\
\hline$\left[\mathrm{Ni}(\mathrm{BIBTS})_{2} \mathrm{Cl}_{2}\right]$ & Grey & 2.97 & 2.4 & $\begin{array}{c}52.00 \\
(52.05)\end{array}$ & $\begin{array}{c}4.31 \\
(4.37)\end{array}$ & $\begin{array}{c}20.12 \\
(20.23)\end{array}$ & $\begin{array}{c}8.41 \\
(8.48)\end{array}$ & $\begin{array}{l}10.05 \\
(10.24)\end{array}$ \\
\hline$\left[\mathrm{Cu}(\mathrm{BIBTS})_{2} \mathrm{Cl}_{2}\right]$ & $\begin{array}{l}\text { Dark } \\
\text { green }\end{array}$ & 1.94 & 6.8 & $\begin{array}{c}51.61 \\
(51.69)\end{array}$ & $\begin{array}{c}4.32 \\
(4.34)\end{array}$ & $\begin{array}{c}20.17 \\
(20.09)\end{array}$ & $\begin{array}{c}9.09 \\
(9.12)\end{array}$ & $\begin{array}{l}10.10 \\
(10.17)\end{array}$ \\
\hline$\left[\mathrm{Zn}(\mathrm{BIBTS})_{2} \mathrm{Cl}_{2}\right]$ & White & Dia & 1.3 & $\begin{array}{c}51.50 \\
(51.55) \\
\end{array}$ & $\begin{array}{c}4.29 \\
(4.33) \\
\end{array}$ & $\begin{array}{c}20.01 \\
(20.04) \\
\end{array}$ & $\begin{array}{c}9.30 \\
(9.35) \\
\end{array}$ & $\begin{array}{c}10.01 \\
(10.15) \\
\end{array}$ \\
\hline
\end{tabular}

$C=$ Carbon, $H=$ Hydrogen, $N=$ Nitrogen and $M=$ Metal

Table 2. Antimicrobial data

\begin{tabular}{cccccc}
\hline & \multicolumn{5}{c}{ Zone of Inhibition, mm } \\
\cline { 2 - 6 } Compound & \multicolumn{4}{c}{ Gram Positive } & \multicolumn{2}{c}{ Gram Negative } & Fungi \\
& $\begin{array}{c}\text { Staphylococcus } \\
\text { aureus }\end{array}$ & Staphylococcus & Pseudomonas & Escherichia & Candida \\
facurginosa & coli & albicans \\
\hline BIBS & 09 & 14 & 17 & NI & 8 \\
{$\left[\mathrm{Co}(\mathrm{BIBS})_{2} \mathrm{Cl}_{2}\right]$} & 16 & 13 & 18 & 23 & 16 \\
{$\left[\mathrm{Ni}(\mathrm{BIBS})_{2} \mathrm{Cl}_{2}\right]$} & 10 & $\mathrm{NI}$ & 13 & $\mathrm{NI}$ & 6 \\
{$\left[\mathrm{Cu}(\mathrm{BIBS})_{2} \mathrm{Cl}_{2}\right]$} & 18 & 16 & 17 & 17 & NI \\
{$\left[\mathrm{Zn}(\mathrm{BIBS})_{2} \mathrm{Cl}_{2}\right]$} & 20 & 17 & 16 & 20 & NI \\
BIBTS & 21 & 16 & 20 & 19 & 17 \\
{$\left[\mathrm{Co}(\mathrm{BIBTS})_{2} \mathrm{Cl}_{2}\right]$} & 19 & $\mathrm{NI}$ & 18 & 20 & 16 \\
{$\left[\mathrm{Ni}(\mathrm{BIBTS})_{2} \mathrm{Cl}_{2}\right]$} & $\mathrm{NI}$ & 09 & 15 & 10 & 9 \\
{$\left[\mathrm{Cu}(\mathrm{BIBTS})_{2} \mathrm{Cl}_{2}\right]$} & 20 & 11 & $\mathrm{NI}$ & 19 & 15 \\
{$\left[\mathrm{Zn}(\mathrm{BIBTS})_{2} \mathrm{Cl}_{2}\right]$} & 20 & 13 & $\mathrm{NI}$ & 20 & 17 \\
Standard & 10 & 14 & 18 & 12 & 17 \\
DMSO & $\mathrm{NI}$ & $\mathrm{NI}$ & NI & NI & NI \\
\hline
\end{tabular}


General procedure for the synthesis of BIBS and BIBTS Mannich base ligands

Mannich Bases were prepared by a solution of benzimidazole $(0.005 \mathrm{~mol})$ in $10 \mathrm{~mL}$ ethanol, $0.005 \mathrm{~mol}$ of secondary amine semicarbazide for BIBS/ thiosemicarbazide for BIBTS and $0.005 \mathrm{~mol}$ of benzaldehyde and then the reaction mixture was refluxed for $8 \mathrm{~h}$. On cooling, the yellowish product formed was filtered, dried and recrystallised from acetone (Scheme 1).

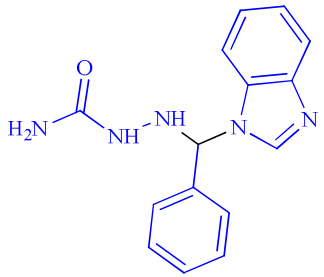

BIBS

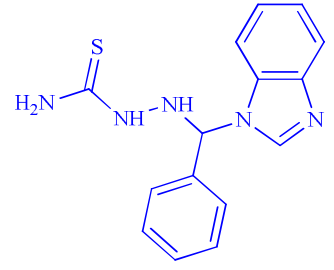

BIBTS

Scheme 1. Structure of synthesied ligands BIBS and BIBTS

\section{2-((1H-benzo[d]imidazol-1-yl)(phenyl)methyl)hydrazinecarboxamide (BIBS)}

Yield 79\%; Mol. Formula: $\mathrm{C}_{15} \mathrm{H}_{15} \mathrm{~N}_{5} \mathrm{O}$; IR ( $\mathrm{KBr} \mathrm{v}_{\max }$ in $\mathrm{cm}^{-1}$ ) (Figure 1): 3460 (N-H Str), 3062 (aromatic C-H Stretch). 1690 (C=O Stretch), 1648 (N-H Bend), 1246 (C-N Str); ${ }^{1} \mathrm{H}$ NMR $\left(\mathrm{CDCl}_{3} \delta \mathrm{ppm}\right): 9.0$ (s, H N-H proton either side of carbonyl group), 7.2 (s, H NH proton nearer to methane proton), 7.3-7.6 (m, Ar- $\mathrm{CH}), 1.2$ (s, H CH of methine); ${ }^{13} \mathrm{C}$ NMR $\left(\mathrm{CDCl}_{3} \quad \delta \quad \mathrm{ppm}\right): 157.13$ (Carbonyl carbon), 110.0-143.8 (Aromatic carbons of Benzimidazole) and $88.0(\mathrm{CH})$. Mass: $\mathrm{m} / \mathrm{z}=281$.

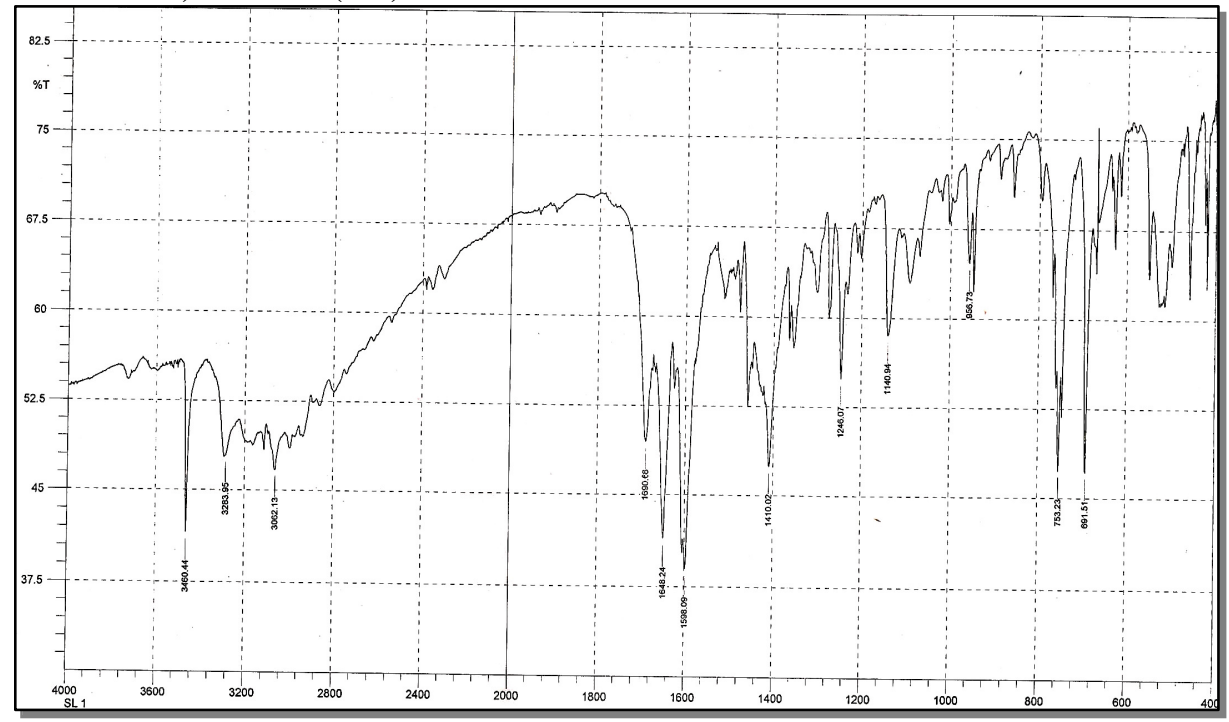

Figure 1. IR Spectrum of BIBS

2-((1H-benzo[d]imidazol-1-yl)(phenyl)methyl)hydrazinecarbothioamide (BIBTS)

Yield 78\%; Mol. Formula: $\mathrm{C}_{15} \mathrm{H}_{15} \mathrm{~N}_{5} \mathrm{~S}$; IR $\left(\mathrm{KBr} \mathrm{v}_{\max }\right.$ in $\left.\mathrm{cm}^{-1}\right)$ : 3460 (N-H Str), 3052 (aromatic CH Stretch), 1648 (N-H Bend), 1258 (C-N Str), 1049 (C=S Stretch); ${ }^{1} \mathrm{H}$ NMR $\left(\mathrm{CDCl}_{3} \delta \mathrm{ppm}\right)$ (Figure 2): 9.0 (s, H N-H proton either side of carbonyl group), 7.2 (s, $\mathrm{H} \mathrm{NH}$ proton nearer to methane proton), 7.3-7.6 (m, $\mathrm{Ar}-\mathrm{CH}), 1.2$ (s, $\mathrm{H} \mathrm{CH}$ of methine); ${ }^{13} \mathrm{C} \mathrm{NMR}\left(\mathrm{CDCl}_{3} \delta \mathrm{ppm}\right)$ : 
157.13 (Carbonyl carbon), 110.0-143.8 (Aromatic carbons of benzimidazole) and $88.0(\mathrm{CH})$. Mass: $m / z=297$.

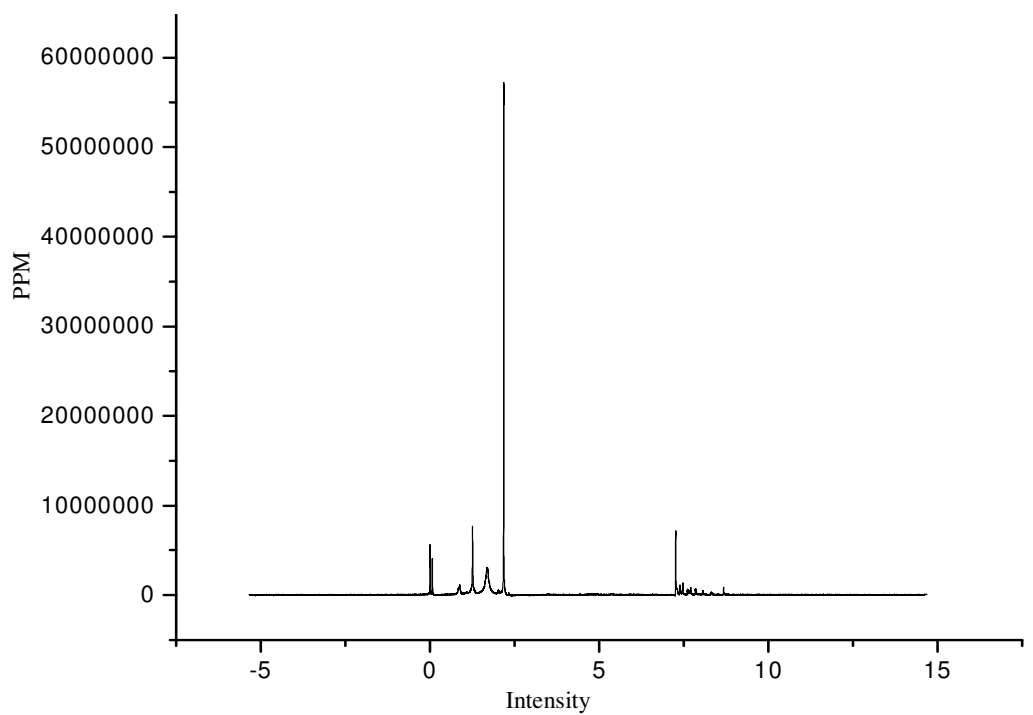

Figure 2. ${ }^{1} \mathrm{H}$ NMR Spectrum of BIBTS

\section{Synthesis of metal complexes of BIBS and BIBTS}

$\mathrm{Co}(\mathrm{II}), \mathrm{Ni}(\mathrm{II}), \mathrm{Cu}(\mathrm{II})$ and $\mathrm{Zn}$ (II) chloro complexes were prepared by using BIBS or BIBTS as ligand. An ethanolic solution of Mannich base [BIBS or BIBTS (0.005 mol)] was refluxed for $c a$. $2 \mathrm{~h}$ with a methanolic solution of metal salts. The resulting reaction mixture was then filtered, washed with ethanol and dried under vacuum (Scheme 2).

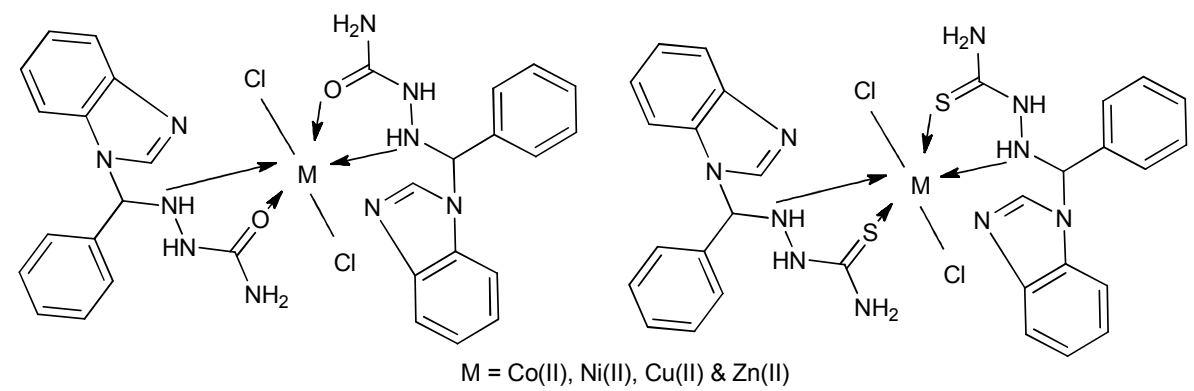

Scheme 2. Structure of synthesed metal complexes of BIBS and BIBTS

\section{IR spectral data}

The IR spectrum of the ligands BIBS and BIBTS have several prominent bands appearing at 3460,1690 and $1049 \mathrm{~cm}^{-1}$ due to $v(\mathrm{~N}-\mathrm{H}), v(\mathrm{C}=\mathrm{O})$ and $v(\mathrm{C}=\mathrm{S})$ stretching modes, respectively. Comparison of the IR spectra of the Mannich base (BIBS and BIBTS) and its metal complexes indicates that the Mannich base is coordinated to the metal atom by two sites, thus suggesting that the ligand acts as bidentate ligand. The band appears at $325 \mathrm{~cm}^{-1}$ in all the complexes assigned to $\mathrm{M}-\mathrm{Cl}$ stretching vibration. The $\mathrm{v}(\mathrm{C}=\mathrm{O})$ amide vibration at $1690 \mathrm{~cm}^{-1}$ in the free ligand BIBS is shifted and observed around $1675 \mathrm{~cm}^{-1}$ for $\mathrm{Co}$ (II), $1670 \mathrm{~cm}^{-1}$ for $\mathrm{Ni}$ (II), 
$1680 \mathrm{~cm}^{-1}$ for $\mathrm{Cu}(\mathrm{II})$ and $1660 \mathrm{~cm}^{-1}$ for $\mathrm{Zn}(\mathrm{II})$ chloro complexes, respectively indicating coordination of the nitrogen of the amide group to the metal atoms ${ }^{15}$. The $v(C=S)$ stretching $1049 \mathrm{~cm}^{-1}$ in the free ligand BIBTS is shifted to higher frequency and observed around 1052 for $\mathrm{Co}(\mathrm{II}), 1083$ for $\mathrm{Ni}(\mathrm{II}), 1059$ for $\mathrm{Cu}(\mathrm{II})$ and 1055 for $\mathrm{Zn}$ (II) chloro complexes, respectively indicating coordination of sulfur atom of the $\mathrm{C}=\mathrm{S}$ moiety to the metal atoms ${ }^{16}$.

\section{Electronic absorption spectra and magnetic moment measurements}

The electronic absorption spectra are often very helpful in the evaluation of results furnished by other methods of structural investigation. It is also used for assigning of metal ions in the complexes based on the position and number of $\mathrm{d}-\mathrm{d}$ transition peaks. The electronic spectra of Co(II) complexes of BIBS and BIBTS shows bands at $16520 \mathrm{~cm}^{-1}$ and $20200 \mathrm{~cm}^{-1}$ respectively due to ${ }^{4} \mathrm{~T}_{1 \mathrm{~g}}(\mathrm{~F}) \rightarrow{ }^{4} \mathrm{~A}_{2 \mathrm{~g}}(\mathrm{~F})$ transition which correspond to intra-ligand charge transfer transitions. The observed results said that the complexes having octahedral geometry and it further confirmed by the magnetic moment value of 4.60 B.M. for BIBS and 5.08 B.M. for BIBTS complexes respectively. Electronic spectra of $\mathrm{Ni}(\mathrm{II})$ complexes of BIBS exhibit two electronic spectral bands at 17500 and $25365 \mathrm{~cm}^{-1}$ which can be assigned to ${ }^{2} \mathrm{~A}_{2 \mathrm{~g}}(\mathrm{~F}) \rightarrow{ }^{3} \mathrm{~T}_{2 \mathrm{~g}}(\mathrm{~F})\left(\mathrm{V}_{1}\right)$ and ${ }^{3} \mathrm{~A}_{2 \mathrm{~g}}(\mathrm{~F}) \rightarrow{ }^{3} \mathrm{~T}_{1 \mathrm{~g}}(\mathrm{~F})\left(\mathrm{V}_{2}\right)$ transitions in an octahedral field. The $v_{2} / v_{1}$ value is 1.62 which is in the usual range reported for an octahedral $\mathrm{Ni}$ (II) complexes and further supported by the magnetic moment value of 3.55 B.M. The Ni(II) complex of BIBTS exhibits a $14536 \mathrm{~cm}^{-1}$ due to ${ }^{3} \mathrm{~A}_{2 \mathrm{~g}}(\mathrm{~F}) \rightarrow{ }^{3} \mathrm{~T}_{2 \mathrm{~g}}(\mathrm{~F})$ transition $\left(v_{1}\right)$, another at $15269 \mathrm{~cm}^{-1}$ due to ${ }^{3} \mathrm{~A}_{2 \mathrm{~g}}(\mathrm{~F}) \rightarrow{ }^{3} \mathrm{~T}_{2 \mathrm{~g}}(\mathrm{~F})$ transition $\left(\mathrm{V}_{2}\right)$ and also at $23806 \mathrm{~cm}^{-1}$ due to ${ }^{3} \mathrm{~A}_{2 \mathrm{~g}}(\mathrm{~F}) \rightarrow{ }^{3} \mathrm{~T}_{1 \mathrm{~g}}(\mathrm{P})$ transitions $\left(v_{3}\right)$ respectively. The magnetic moment value of 2.97 B.M. suggest octahedral geometry. The value of magnetic moment 1.94 B.M. for BIBS and BIBTS indicates the presence of an unpaired electron on $\mathrm{Cu}$ (II) ion. The electronic absorption band of medium intensity for the $\mathrm{Cu}$ (II) BIBS complex at $12531 \mathrm{~cm}^{-1}$ and $\mathrm{Cu}$ (II) BIBTS complex at 14960 $\mathrm{cm}^{-1}$ which is attributed to the transition of ${ }^{2} \mathrm{E}_{\mathrm{g}} \rightarrow{ }^{2} \mathrm{~T}_{2 \mathrm{~g}}$ characteristic to a distorted octahedral geometry. The $\mathrm{Zn}$ (II) complex does not exhibit any characteristic d-d transition and its spectrum subjected only by a charge transfer band due to distribution of electrons between metal and ligands and also found to be diamagnetic in nature.

\section{${ }^{I} H$ NMR spectrum of Zn(II) chloro complexes of BIBS and BIBTS}

The ${ }^{1}$ HNMR spectra of the ligand BIBS and BIBTS and its Zn(II) complex were recorded by employing TMS as internal reference at ambient temperature. The ligand BIBS and BIBTS shows signals at $\delta 9.0$ (s, H N-H proton either side of carbonyl group) is shifted to slightly downfield at $\delta 9.2$ which reveals the bonding of the amide carbonyl oxygen to $\mathrm{Zn}$ (II) complex and signals at $\delta 7.2$ (s, $\mathrm{H} \mathrm{NH}$ proton nearer to methane proton) is shifted slightly and appeared at $\delta 7.4$ in the complex. This is an indication of the coordination of amide nitrogen to the metal ion.

\section{EPR spectral studies}

EPR spectrum of copper complex provides information which is important in studying the metal ion environment ${ }^{17}$. The magnetic moment measurement values of $\mathrm{Cu}(\mathrm{II})$ complexes of BIBS and BIBTS complexes found to be 1.94 B.M. which corresponds to the presence of one unpaired electron in the complex. This has been further supported by EPR spectra. Daniel Kivelson and Robert Neiman ${ }^{18}$ have reported that for covalent environment, $g_{\|}$value is less than 2.3 and for ionic environment it may be equal to or greater than 2.3. Since $\mathrm{g}_{\|}$ values of these has been further supported ${ }^{19}$ by the value of spin-orbit coupling constant $(\lambda)$ 
that can be calculated by using the expression $g_{\text {avg }}=\frac{1}{3}\left[2 g_{\|}+g_{\perp}\right]$.

The measure of symmetry of the $\mathrm{Cu}(\mathrm{II})$ complexes of BIBS and BIBTS is in terms of $\mathrm{g}$ values, that is, $\mathrm{g}>2.04$ for BIBS complex and $\mathrm{g}>2.19$ for BIBTS indicates that the ground state $\mathrm{Cu}$ (II) ion is predominantly the $d_{x^{2}-y^{2}}$ orbital. The $\mathrm{g}$ values of these complexes are found to be less than 2.3 indicating the covalent nature of the complexes. This has been further supported by the spin-orbit coupling constant $(\lambda)$ value of $-465 \mathrm{~cm}^{-1}$. The $\alpha^{2}$ values of these complexes are found to be 0.72 and 0.69 suggesting that there is appreciable covalency in the complexes. The elongated octahedral geometry of the complexes have been established from the relation $\mathrm{g}_{\|}>\mathrm{g}_{\perp}>2.04$.

\section{Antimicrobial screening}

The zone of inhibition values of BIBS and BIBTS and its complexes were presented in Table 2. It is clear from the table that the observed MIC values indicate that most of the complexes have higher antimicrobial activity than free ligand (BIBS and BIBTS). The chelation theory explains that a decrease in the polarizablity of the metal can change the lipophilicity or hydrophobicity of complexes. These properties are now seen as important parameters related to membrane permeation in biological systems. Many of the processes of drug disposition depend on the ability or inability to cross membranes and hence there is a high correlation with measures of lipophilicity. Moreover, many of the proteins involved in drug disposition have hydrophobic binding sites, further adding to the importance of lipophilicity.

By consideration of the structures of compounds that exhibit antimicrobial activity, it can be concluded that the metal moiety may play a role in determining the antibacterial activity. It is also concluded that the cell wall is essential to the survival of bacteria and some antibiotics are able to kill bacteria by inhibiting a step in the synthesis of peptidoglycan. Gram-positive bacteria possess a thick wall containing many layers of peptidoglycan and teichoic acids, but in contrast, Gram-negative bacteria have a relatively thin cell wall consisting of a few layers of peptidoglycan surrounded by a second lipid membrane containing lipopolysaccharides and lipoproteins. These differences in cell wall structure can produce difference in antibacterial susceptibility and some antibiotics can kill only Gram-positive bacteria and is ineffective against Gram-negative pathogens. ${ }^{20}$ The zone of inhibition values was determined at the end of incubation period of $24 \mathrm{~h}$ at $35^{\circ} \mathrm{C}$. During this period, the test solution diffused and the growth of the inoculated microorganisms was affected. It has been observed from the result (Table 2) that the metal complexes have a higher activity than that of the free ligand and the standard due to higher lipophilic nature of the complexes. The antimicrobial activity of BIBS and BIBTS ligand as well as its metal complexes was screened in Figure 3.
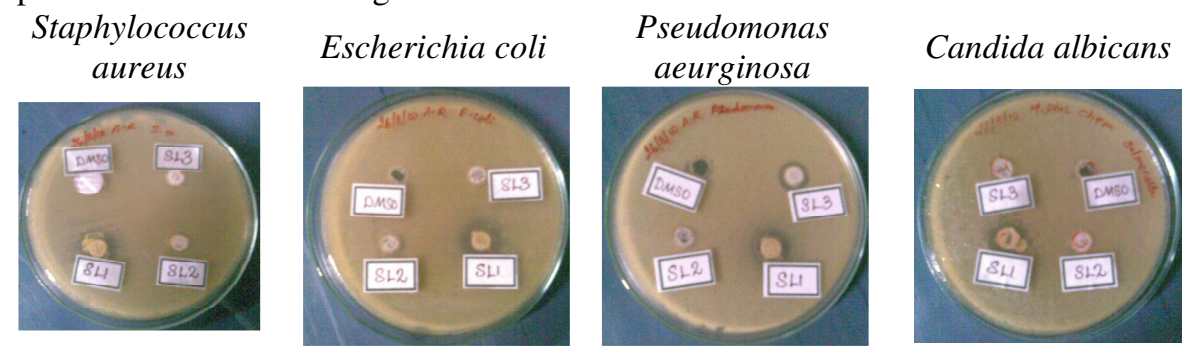

Figure 3. Antimicrobial screening of BIBS, BIBTS and its metal complexes 


\section{Reference}

1. Selva Ganesan Subramania Pillai, $J$ Chem Sci., 2013, 125(3), 467-482; DOI:10.1007/s12039-013-0405-y

2. Achar K C, Hosamani K M and Seetharamareddy H R, Eur J Med Chem., 2010, 45(5), 2048-2054; DOI:10.1016/j.ejmech.2010.01.029

3. Kucukbay H, Durmaz R, Orhan E and Gunal S, Il Farmaco, 2003, 58(6), 431-437; DOI:10.1016/S0014-827X(03)00068-5

4. Garuti L, Roberti M and Cermelli C, Bioorg Medicinal Chem Lett., 1999, 9(17), 2525-2530; DOI:10.1016/S0960-894X(99)00429-1

5. Gata L, Perna F, Figura N, Ricci C, Holton J, D'Anna L, Miglioli M and Vaira D, $J$ Antimicrob Chemother, 2003, 51(2), 439.-442; DOI:10.1093/jac/dkg085

6. Mohamad Jaber Al-Jeboori, Ahlam Jamil Abdul-Ghani and Ahmed Jasim Al-Karawi. Transition Metal Chem., 2008, 33(7), 925-930.

7. Li Z X, Hu T L, Hong M, Yong F Z, Cui J L, Ming L T and Xian H B, Crystal Growth Design, 2010, 10(3), 1138-1144; DOI:10.1021/cg900980y

8. Chen J Q, Cai Y P, Fang H C, Zheng Y Z, Xu L Z, Gang Z and Zhong Z, Crystal Growth Design, 2009, 9(3) 1605-1613; DOI:10.1021/cg8013317

9. Sarika Verma, Saita Shrivastva and Rashmi Shrivastva, Int J Chem Sci., 2012, 10(2) 664-676.

10. Ayhan-Kilcigil G and Altanlar N, Turk J Chem., 2006, 30 223-228.

11. Anantharam Sreekanth and Prathapachandra Kurup M R, Polyhedron, 2003, 22(2526), 3321-3332; DOI:10.1016/j.poly.2003.07.011

12. Anandaram Sreekanth and Prathapachandra Kurup M R, Polyhedron, 2004, 23(6), 969-978; DOI:10.1016/j.poly.2004.01.006

13. Zahra Afrasiabi, Ekkehard Sinn, Junnan Chen, Yinfa Ma, Arnold L Rheingold, Lev N Zakharov, Nigam Rath and Subhash Padhye, Inorg Chim Acta, 2004, 357(1), 271 DOI:10.1016/S0020-1693(03)00484-5

14. Dimitra Kovala-Demertzi, Mavroudis A Demertzis, John R Miller, Christopher S Frampton, Jerry P Jasinski and Douglas X West, J Inorg Biochem., 2002, 92(2) 137; DOI:10.1016/S0162-0134(02)00493-2

15. Mohamad J Al-Jeboori, Fahad A Al-Jebouri, Muayed A R and Al-Azzawi, Inorg Chem Acta, 2011, 379(1), 163-170; DOI:10.1016/j.ica.2011.10.013

16. Mohamad Jaber Al-Jeboori, Husam H. Al-Tawel and Reyadh Mahmood Ahmad, Inorg Chem Acta, 2010, 363(6) 1301-1305; DOI:10.1016/j.ica.2009.11.040

17. Cotton F A and Wilkinson G, "Advanced Inorganic chemistry", Wiley, New York, 1988, 730.

18. Daniel Kivelson and Robert Neiman, J Chem Phys., 1961, 35, 149, DOI:10.1063/1.1731880

19. J.E. Wertz and J.R. Boton "ESR Elementary theory and Practical applications", $1^{\text {st }}$ Edn., Chapman and Hall NewYork, 1986.

20. Mohammad Shakir, Saji P Varkey and Omar S M Nasman, Polyhedron, 1995, 14(10), 1283-1288; DOI:10.1016/0277-5387(94)00395-U 